\title{
Growth, Inequality and Poverty in Emerging and Transition Economies
}

\author{
Pasquale Tridico
}

Received: 5 March 2009/Accepted: 6 October 2009/Published online: 19 December 2009

(c) The Author(s) 2009. This article is published with open access at Springerlink.com

\begin{abstract}
This paper aims to explore the quality of economic growth in a sample of 50 emerging and transition economies (ETEs), which are countries experiencing a process of fast growth and institutional change. Economic growth during 19952006 is regressed against poverty, inequality and human development variables using OLS cross-country regression models. The main findings are that growth did not reduce poverty and income inequality worsened too. On the one hand, economic growth occurred despite the worsening of income inequality. However, this result does not identify a "U-shaped" Kuznets curve because even after a consistent period of growth, inequality did not decrease and it remained at higher levels. Only countries with higher education levels and public expenditure in strategic dimensions seem to escape from this trap. On the other hand, growth occurred at the expense of an important human development variable i.e., life expectancy, and of an important indicator of democracy, i.e., voice and accountability.
\end{abstract}

Keywords Development $\cdot$ Inequality $\cdot$ Poverty $\cdot$ Institutions

JEL Classification $\mathrm{O} 10 \cdot \mathrm{O} 15 \cdot \mathrm{I} 32 \cdot \mathrm{P} 52$

The paper was written during a visiting research fellowship at the Global and Urban Research Centre (GURU) of Newcastle University, in November-December 2007. The author is very grateful to Prof. Frank Moulaert for his help and support at Newcastle University and to Prof. Fadda for his comments. The usual disclaimer applies.

P. Tridico $(\bowtie)$

Department of Economics, University of Roma Tre, Rome, Italy

e-mail: tridico@uniroma3.it 


\section{Introduction}

World economic growth was well sustained in the last decade, although many industrialised countries, western European in particular, did not experience fast growth. Emerging economies (EEs), such as low-to-middle per capita income economies, and transition economies (TEs), such as former communist countries, are experiencing a process of fast growth and institutional change in most cases. This paper aims first of all to explore the social sustainability and the quality of such growth in those countries. The economic growth that occurred in emerging and transition economies (ETEs) during the period 1995-2006 was, on average, 4.7\%, and above the average world growth. The paper examines, in particular, whether, this growth resulted in income distribution, measured as a reduction of the Gini coefficient, and in a reduction of poverty, measured by a cut-off line of $\$ 4$ a day. Secondly, the paper addresses important issues of the economic development process, such as the dynamics of life expectancy and education, and of human development variables more generally. In particular the paper tries to understand whether or not economic growth increased human development in ETEs.

Such an issue is crucial to the identification of a process of economic growth with a process of economic development. In their widely quoted economic development book, Perkins et al. (2007) stress the difference between economic growth (understood as the rate of growth in goods and services produced) and economic development (which involves economic growth together with change in some human development variables, such as life expectancy, infant mortality, education, and other goals such as environment sustainability, political democracy, income distribution, participation, access to resources, etc.). Cypher and Dietz (2004) also make such a differentiation between economic growth and (economic) development. The latter "...encompasses a wide range of social and human goals that, while including the level of income and economic growth, goes well beyond this as well" (Cypher and Dietz 2004), p. 29. This differentiation must not be confused with that discussed among institutional economists ${ }^{1}$ who perceive economic growth as a static phenomenon and economic development as a wider perspective of development that includes structural and institutional change, social dynamics and cultural change (Myrdal 1974). However, it has to be said that these two perspectives of economic development (the one put forward by Perkins et al. (2007) and Cypher and Dietz (2004), and the other put forward by Myrdal 1974) would easily converge in the end because, as Myrdal (1974), p. 729 himself states, economic development would bring about improvements in health, education and other collective goods.

Through a series of cross-country regressions, using OLS models, the paper assesses the type of development in a sample of 50 ETEs. Economic growth during 1995-2006 is regressed against poverty, inequality and human development variables. The main findings are that growth did not reduce poverty and that inequality increased, on average, among ETEs during this period. Moreover, economic growth occurred at the expense of an important human development

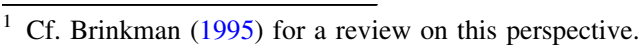




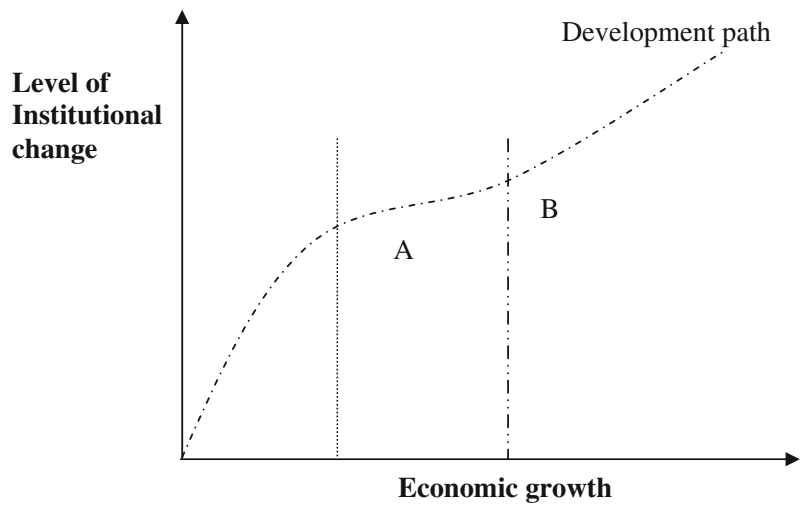

Fig. 1 The Development Path

variable i.e., life expectancy and an important indicator of political democracy, i.e., voice and accountability.

The rest of the paper is organised as follows: "Growth, Inequality and Poverty: a Brief Review" presents an essential review on poverty, inequality and growth; "Institutional Change and Economic Growth in ETEs" analyses more deeply the institutional change occurring in ETEs, putting forward a model of development path (Fig. 1)2 " "ETEs: a Description of the Sample" describes the sample of ETEs; "Poverty and Inequality in Transition and Emerging Economies" shows the results of the OLS regression models on poverty and inequality in ETEs; "Conclusion" concludes the paper.

\section{Growth, Inequality and Poverty: a Brief Review}

In the terminology of the International Monetary Fund (IMF) and of the World Bank (WB), economic development is not just about economic growth in general but a particular kind of economic growth, identified by the words "high-quality growth" (HQG), which both the IMF and the WB claim to promote (IMF 1995). In particular, IMF defines HQG as “...growth that is sustainable, brings lasting gains in employment and living standards and reduce poverty. HQG should promote greater equity and equality of opportunity. It should respect human freedom and protect the environment"; and it should "... bear the primary responsibility for the care, nutrition, and education. Achieving HQG depends, therefore, not only on pursuing sound economic policies, but also on implementing a broad range of social policies" (IMF 1995), p. 286. Hence, great emphasis is put on reduction in levels of poverty and inequality, together with the pursuit of social goals, such as improved

\footnotetext{
${ }^{2}$ Note: during the first period, from the origin to the point A, the speed of institutional change is faster than the speed of economic growth. In the second period, from point A to B, the economic growth is faster than the speed of the institutional change. In other words, economic growth follows the institutional change
} 
health and education, which should increase accordingly during the process of economic growth.

Poverty and inequality are key concerns nowadays among economists of development. However, social attitudes towards poverty and inequality can change through time, basically because tolerance of high levels of poverty and inequality varies across countries, cultures, and times. Western societies have become less tolerant against poverty over time; East Asia, mainly following Confucianism, does not, in general, tolerate high economic inequality. Unfortunately this promising field of research has not produced many cross-cultural studies. Alexander and Kumaran (1992) studied culture and development in India. They discovered that the lowest tolerance of inequality is not in the richest States of India, but in those with the highest education levels. If it were possible to make some generalization on the basis of this, one could say that variation in values that concern inequality is influenced by education. Indeed within both developed and less developed countries, those which have achieved higher levels of education seem to show less tolerance towards inequality and poverty (Cypher and Dietz 2004).

Gary Fields (1989) reviewed all the major empirical studies on growth, inequality and poverty and found out that there is no general predictable relationship between inequality and GDP growth; the relationship can work in both ways round. Nevertheless, there seems to be some evidence of poverty reduction associated with economic growth. However, he did not conclude that economic growth reduces poverty. It is possible that during GDP expansion the poor become less poor, and during GDP contraction the poor become even poorer (Dollar and Kraay 2001). However, eradicating poverty can take generations and it is not only a matter of economic growth. Moreover, social policies and income distribution are, as will be shown below, strictly linked to poverty reduction. Hence, as Myrdal (1974) and many others, such as Pronk (1993) and Street (1987) argue, a holistic approach is required to defeat poverty. Poverty has a social and political dimension; both should be addressed in order to arrive at a deeper understanding of the meaning of poverty, its causes and its consequences. Poverty alleviation comes as a result of a complex analysis and of the implementation of strategies that bring together both different disciplines and the poor themselves in the process of policy-making.

\section{Poverty}

The World Bank claims the defeat of poverty as its main target, and policies which "make poverty a dream" are now at the core of its agenda. Over time, however, WB policies on poverty have changed consistently. During the 1960s, the WB believed that the best way to reduce poverty in Less Developed Countries (LDCs) was a rapid industrialisation. During the 1970s the WB understood the need to develop the rural sector in LDCs as a vehicle for both economic growth and poverty reduction. In the 1980s, the WB was more committed to structural adjustment, as the IMF was implementing structural adjustment programmes in Developed Countries (DC). In the 1990s the WB embraced a more general approach to combat poverty involving investments in human capital, macroeconomic adjustment, fostering economic growth, environment attention, etc. Finally, in the 2000s, the WB and the IMF 
together developed a new approach to poverty reduction, the so called Poverty Reduction Strategy Papers (PRSPs). PRSPs set policies and agendas to reduce poverty and integrate economic, social and environmental issues into a general framework. They are developed in a participatory way, with the involvement of individuals, NGOs, international organisations, local and national authorities (Marcus and Wilkinson 2002).

So far the aim of defeating world poverty has not been achieved; from the analysis in this paper it has emerged that growth did not contribute to poverty reduction between 1995 and 2006. Most of the criticism directed at the WB and the IMF lies in the fact that the approach they adopted towards LDCs during the 1980s and the 1990s relied exclusively on structural adjustment and economic growth, transplanting policies and institutions from developed countries. The World Bank (2000) estimates that poverty, measured with a cut-off line of poverty of $\$ 1$ a day, increased from 1,116 million to 1,200 million people from 1985 to 1998 . With a cutoff line of $\$ 2$ a day, people falling within the poverty trap form nearly half of the global population $\left(2.8\right.$ billion). ${ }^{3}$ In terms of percentages, while poverty is stable in Sub-Saharan Africa (46.3\% of population) and in Latin America and the Caribbean (15.6\% of population), it fell in the Middle East and North Africa (from 4.3 to $1.9 \%$ ), in Southern Asia (from 44.4 to $40 \%$ ) and in particular in Eastern Asia (from 26.6 to $15.3 \%$ ).

In Sub-Saharan Africa and in many other LDCs the main problem causing poverty seems to be deprivation of basic human necessities such as food, basic medicines, water, illiteracy etc. (Cypher and Dietz 2004). In richer countries, such as ETEs with low-to-middle per capita income, the main problem causing poverty seems to be also deprivation (Sen 1999); however, different forms of deprivation are prevalent here, such as education, nourishment, health, employment etc. Such deprivations, in both groups of countries, do not allow people to develop their capabilities and to achieve liberation from poverty. ${ }^{4}$ In many cases, these deprivations do not depend on money, but a cut-off line of poverty of $\$ 1$ or $\$ 4$ a day can be considered just as a proxy for such a problem.

In addition, when poverty is measured through the concept of "poverty gap", 5 the strong link between poverty and distribution immediately becomes clear. In fact, the poverty gap appears to be relatively modest in size when compared to current income in LDCs. Theoretically, the poverty gap can be interpreted as the amount of income that must be created and received by the poor in order to bring income above the poverty line (Cypher and Dietz 2004), p. 7. For instance the poverty gap,

\footnotetext{
3 Cf. World Bank (2000:3 and 13).

${ }^{4}$ On this concept is drawn the Human Poverty Index (HPI), a composite index which measures deprivations in the three basic dimensions captured in the human development index: a long and healthy life (health), knowledge (education) and a decent standard of living (income) (UNDP, 2006).

5 The poverty gap is the percentage by which the income of the poor falls short of the poverty line, measured usually as a percentage of total consumption of the country. In other terms, it is the amount of additional income needed to raise all the poor above the poverty line. This measure would help towards a better understanding of the severity of the poverty. For instance, if a country has half of its population in poverty but each person is only $\$ 2$ away, per year, from the poverty level, it is in a better position than a country with half of its population in poverty but each person is $\$ 50$ away, per year, from the poverty level.
} 
in the 1990s, was around 10-12\% in Sub-Saharan Africa and Southern Asia and around $2 \%$ in the rest of LDCs (World Bank 1990). These figures underline that in the final analysis eradicating poverty is a political economy matter and not a technical one. However, it has to be added that distribution alone would not be enough for a permanent poverty reduction; a process of development would have to reproduce basic need satisfactions, goods and jobs.

\section{Inequality}

The very foundation of the problem of inequality is the concept of social welfare. According to the utilitarian approach, social welfare is the sum of individual welfare. Social welfare improvements are not possible (or would not be "Pareto efficient") by re-distributing resources from one individual to another, because a "Pareto" improvement is only a situation in which it is possible to make someone better off, without making someone else worse off. On the other hand, an egalitarian approach would consider re-distribution of resources to avoid the situation where an individual could become richer by taking advantage of the fact that the other is in poor health or in poor education, or is handicapped (Sen 1973). In this latter approach, the application of the Rawls criterion would be the best policy; the aim is not individual welfare but the level of welfare in the society. If one individual (A) has a lower level of welfare that another (B), and if B can be made better off by redistributing resources from $\mathrm{A}$, then the Rawls criterion of justice requires that $\mathrm{B}$ should have sufficiently more income to make B's utility equal to A's. In Rawlsian thinking, inequalities have to be adjusted following two principles: (1) offices and positions must be open to everyone under conditions of fair equality of opportunity; (2) they have to be of greatest benefits for the least-advantaged members of the society (Rawls 1971), p. 303. To be applied, these criteria require more than meritocracy. 'Fair equality of opportunity' requires not only that positions are distributed on the basis of merit, but also that all have equal opportunity, in terms of education, health etc., to acquire those skills on the basis of which merit is assessed. The application of these principles would, in the end, produce much greater advantages for the society as a whole.

Another way to look at the problem of inequality is through social peace and cohesion. Sen (1973) saw inequality as strictly linked to the concept of rebellion and indeed the two phenomena are linked in both ways. Inequality causes rebellion, but it may happen that income inequality may increase after a rebellion where it brings power to a specific apparatus or a nomenclature or a social class; this has happened many times in history when, for instance, rebellions were led by army generals or by elites of nobles. In several transition economies, inequality increased after a "rebellion" which brought to power oligarchs. In particular, in the former Soviet Union inequality increased dramatically after the 1991 August Coup which deposed Soviet president Mikhail Gorbachev and dissolved the URSS. In some African countries, such as Congo, Sudan etc. the same happened: rebellions, carried out by generals and warlords, deposed previous authoritarian or less authoritarian regimes, but such a change brought about an increase in inequality. Nowadays, economists try to capture a causality nexus (inequality $\rightarrow$ rebellion $\rightarrow$ inequality) through the 
use of some modern governance indicators such as political stability. The link between political stability and inequality is demonstrated in numerous empirical works such as Alesina and Perotti (1996) and Easterly (2001), where it emerges that income inequality increases during political instability.

An interesting explanation of inequality in the Americas is put forward by Sokoloff and Engerman (2000), who, in order to explain inequality in wealth, human capital and political power, suggest an institutional explanation, historically founded, which lies in the initial roots of the factors of endowment of the respective colonies. In general, political institutions set up by the Spaniards and Portuguese in Latin America were different from the ones set up by the British in North America. Moreover, the latter sent educated people and skilled work forces, along with the lords, to the New World, and these started to build their own future; while the Spaniards and the Portuguese did not encourage massive migration from the motherland, but sent landlords who basically exploited slaves from Africa.

One of the first cross-country works on inequality was made by Kuznets (1955). He showed that in the early stage of economic growth income tends to be unequally distributed among individuals. In the early stage of a growth process, over time, the distribution of income worsens. In the later stages, national income starts to be more equally distributed. Hence, inequality declines in the end, after the country has accomplished the "U"-shaped trajectory. Several later empirical studies confirmed this relationship (Chenery and Syrquin 1975; Ahluwalia 1976). The reason for such a relationship was attributed to structural changes, which at the beginning of the "transition" bring about job losses and inequalities.

Nevertheless, the implicit trade-off behind the Kuznets curve (economic growth/ inequality) and the idea that an increase in inequality is sometimes necessary for a rapid growth has been often criticized (Atkinson 1999). An alterative hypothesis to explain why income inequality differs among countries is put forward by Milanovic (1994), who shows that inequality decreases in richer societies because social attitudes towards inequality change as those societies get richer, and inequality is less tolerated. Birdsall and Sabot (1994) showed, contrary to the Kuznets hypothesis, that inequality may be a constraint for growth and, if inequality is lowered, then a country could have a GDP per capita $8.2 \%$ higher than a country with income inequality 1 standard deviation higher.

A similar hypothesis is suggested by Voitchovsky (2005), p. 273 who, however, stresses the shape of the distribution and suggests that inequality at the top end of the distribution is positively associated with growth, while inequality lower down the distribution is negatively related to subsequent growth. Moreover, empirical evidence in cross-country analysis, from Latin American to East Asian Countries, would pose the question why Latin America has high inequality and low growth and, on the contrary, why East Asia has high growth and low inequality. Birdsall and Sabot (1994) suggest that it is a matter of policies and social attitude towards inequality. In Latin America, dictators, generals and the ruling classes acted, for a long time after WWII, with little respect for the poorest part of their society, implementing fiscal and trade policies that provided few benefits to the poor. On the contrary, in East Asia the ruling classes were more aware of social needs, and implemented policies such as land reforms, public housing, public investments in 
rural infrastructures and public education which had a positive effect on both growth and income distribution; better educated people can get a better job and earn more; public investment in the rural sector can bring farmer productivity and income higher; public housing and other social services can increase the purchasing power of people, and so forth.

\section{Institutional Change and Economic Growth in ETEs}

Emerging and transition economies are countries which are experiencing a huge process of institutional change, involving both a social and cultural transformation and a political and economic reform (Kornai 2006; Mauro 2000). ${ }^{6}$ However, in order to be socially sustainable and macro-economically stable, the incumbent process of institutional change in ETEs has to be consistent: the change occurring in the formal sphere of the institutional framework (which involves laws, organization and state institutions) should move coherently with that in informal institutions i.e., with social rules and uncodified laws and values, which prescribe certain behaviours and affect in several ways the economic behaviour of agents and their choices (Hodgson 2006; Nugent and Lin 1995). Moreover, and most importantly, the change has to guarantee equal gains to people who otherwise would resist the transformation. Inertia towards a new institutional framework occurs when the social benefits of transformation are not universal and where many people, during the transformation, become losers in terms of unemployment, purchasing power, education, etc. (Tridico 2006). Therefore the change should be radical and should involve as well relationships between the various powers, and lobbies (Mabogunje 1989) which are able to change political institutions.

My assumption, concerning political institutions, is that a country which is governed more democratically and where political institutions are oriented towards freedom guarantees, people participation and political rights, is a country where citizens can have some power and can make some lobbying on the governors. Consequently public decisions, in this country, would be more oriented towards collective benefits than a country where the level of democracy and freedom is less marked. The country which enjoys better democracy, freedom and political rights would extend people opportunities more easily than a country where these rights are restricted. Such a restriction would cause lower level of human development and lower economic growth.

Following this approach, development might be defined as a process that involves economic growth and institutional change (Toye 1995). As Kuznets (1965), p. 30 put it in referring to developing countries: "the transformation of an underdeveloped into a developed country is not merely the mechanical addition of a stock of physical capital: it is a thoroughgoing revolution in the patterns of life and a cardinal change in the relative powers and positions of various groups in the

\footnotetext{
6 The term "emerging economy" was coined in 1981 by Antoine Van Agtmael of the World Bank, and refers to countries that are "emerging" from under-development, and are restructuring their economies along market-oriented lines. Cf. Agtmael (2007). Transition economies refer strictly to former communist countries which are transforming their economies from a planned system to market economies.
} 
population". The process of institutional change has to guarantee two important factors: first, a breaking with previous institutions, routines and norms and overcoming "...the resistance of a whole complex of established interests and values" that previously impeded economic growth (Kuznets 1965), p. 30. Secondly, it has to guarantee the distribution of growth and of the social benefits of development. It is crucial therefore to know how to change institutions and how to enforce a new institutional deal which will bring about economic development i.e. improving both living condition, in terms of income and distribution, and quality of life, in terms of health and education. Hence, institutional policies and an active role of the State are needed during such a transformation in order to guarantee a stable and sustainable economic development.

Such a definition of change, strictly connected with the process of economic development, can be summarised by a graph where, on the vertical axis there is the level of institutional change, which involves social, cultural and political change; on the horizontal axis there is the speed of economic growth. These two variables, institutional change and economic growth, identify the path of the development process which, if the speed of change of the two variables is appropriate and consistent, will be positively inclined, as shown approximately in Fig. 1.

This path of development is the one that many current industrialised countries experienced after WWII. In these countries, economic growth, together with a process of institutional change in the system of values, the culture and the society, brought about economic development also, in the sense that poverty was defeated or substantially reduced, inequality was reduced, political democracy was achieved and human development improved, because social policies were implemented and simultaneously an important Welfare State was created. Will ETEs replicate such a development path? I maintain that the type of development will not necessarily be the same, in the sense that institutions and strategies for development can be different. Informal institutions are also different. However, insofar as the specific country strategy includes an appropriate institutional change with consistent social institutions, accompanied by economic growth, the trend of the path could be replicated, although with different policy prescriptions.

Given the concept of institutions as including both formal and informal institutions, changing formal institutions alone in order to achieve another system is no longer sufficient. More important is to "change the mentality" of economic agents. Both prevalent rules and the mentality of agents can be considered in Veblen's sense of shared "habits of thought" (Veblen 1919), p. 273. If the formal economic institutions are neglected, informal institutions and processes of spontaneous forces prevail. These forces fill the power vacuum of the system. Consequently, the transformation would favour better organised groups, elites, the better educated and the groups in a dominant position. Simultaneously, it would cause disadvantages to less organised groups, unskilled workers, the poor and the less well educated.

As a consequence, economic growth, if it occurs, will not be distributed, inequality will rise and poverty will not be defeated. Development would therefore be uneven, opportunities and capabilities for many people would decrease, and there would be many more losers than winners. Moreover, this informal 
institutionalisation may also be parastatal or illegal. Hence, such uncontrolled transformation strongly favours the emergence of organised crime, corrupt bureaucracy, informal economies, negative informal economic networks, rentseeking, illegal lobbies and so forth.

\section{ETEs: a Description of the Sample}

Most of the reputable studies on the dynamics of poverty, inequality and growth, focus more on LDCs and less on ETEs. This is mainly because emerging and transition economics is a relatively new field of research, and a good assessment on the relationship between poverty, inequality and growth would need quite a long time span, 10-15 years minimum. Secondly, all transition economies experienced a huge recession at the beginning of the 1990s, hence economic growth started in many countries in the second half of the 1990s. Therefore, most of the studies on poverty and inequality in transition economies, focus on the worsening of these two variables during the recession period (Atkinson and Miklewright 1992; Milanovic 1995, 1998; Gradstein and Milanovic 2004), and not really on their evolution during a process of growth acceleration.

This paper tries to fill this hole and examines, empirically, poverty, inequality and growth in a wide sample of ETEs. This group consists of two elements: Emerging Economies (EEs) as defined by the World Bank and the IMF i.e., countries with low-to-middle per capita income in a process of institutional reforms and integration in the world economy (IMF 2001; World Bank 1998); and transition economies, i.e., former communist countries such as current members of the Confederation of Independent States (CIS) and Central and Eastern European Countries (CEECs). Of course Emerging Economies and Transition Economies are very different from each other, from many different points of view, historically, socially and economically. However, they are often considered, by international financial organisations such as Morgan Stanley, Grant Thornton, Goldman Sachs and The Economist group, as part of the group of Emerging Economies, broadly speaking, in the sense that they are experiencing a process of reform and of institutional change. Nevertheless, I would say that although Transition Economies can be considered, in some ways, as Emerging Economies, the opposite is not true. Transition economics is a very specific concept that was applied to former communist countries which, after the fall of the Berlin Wall (1989) and the dissolution of the former Soviet Union, began transition from a planned to a market economy. In general, most of these countries were already industrialised and middle per capita income economies. Taking the beginning of the 1990s as a starting point, most of them had better initial conditions than the Emerging economies, in terms of both infrastructure and quality of life (captured by life expectancy, poverty levels, infant mortality, education, etc.).

Emerging economies can be small, medium and large, and, in general, they appear on the global scene because they are becoming more open, in terms of trade and flows of foreign investments. Brazil, China and Tunisia, for instance, are part of the category of emerging economies because they have been experiencing 
a process of reform over the past decade, with openness, economic growth, institutional and structural change. By this definition, some European countries, such as Spain and Ireland, could have been considered as emerging economies in the 1980s and 1990s when they experienced fast growth and structural change. For this reason I include them in this analysis as reference countries for current emerging economies.

However, since the aim of this paper is to look at the effects of economic growth on income distribution and poverty I selected, from among ETEs, a group of 48 countries that experienced a growth acceleration process in the last 11 years (1995-2006). A growth acceleration is defined by Rodrik et al. (2005) p. 305 as an increase in per-capita growth of 2 percentage points or more for at least 8 years. ${ }^{7}$ In this way I included only the ETEs that grew at an average rate of more than $2 \%$ in the period $1995-2006 .{ }^{8}$ Moreover, I started the cross-section analysis from 1995 because many transition economies experienced a huge recession at the beginning of the 1990s.

Average growth in these countries during 1995-2006 was 4.71\%; this was above the world average growth of $4.33 \%$ (IMF 2007). At the same time, the average income inequality, as measured by the Gini coefficient, grew in the same period (1993-2004), reaching an average level of 39\%; the average of Gini variation was $+7 \%$; poverty, on average, decreased from 52 to $42 \%$, as measured by a cut-off line of $\$ 4$. However, the average of poverty variation was $+20 \%$, showing that many countries experienced a huge increased in the poverty level between 1993 and 2004. ${ }^{9}$ Hence, when assessing the quality of economic development also inequality and poverty dynamics need to be addressed, as it will be done below.

\section{Poverty and Inequality in Transition and Emerging Economies}

This section deals with the specific path of development in ETEs. Firstly, I analyse whether ETEs experienced, together with a growth acceleration process, a reduction of poverty, an increase of political democracy, and an improvement of the human development variables. The second part of this section will focus on income distribution. In other words I will explore whether those countries experienced development or just economic growth.

\footnotetext{
7 Rodrik et al. (2005:305).

8 The complete list of countries considered in our sample include the following: Albania, Algeria, Argentina, Armenia, Azerbaijan, Belarus, Bolivia, Botswana, Brazil, Bulgaria, Chile, China, Croatia, Czech Republic, Ecuador, Egypt, Estonia, Georgia, Hong Kong, Hungary, India, Ireland, Israel, Kazakhstan, Republic of Korea, Kyrgyzstan, Latvia, Lithuania, Macedonia TFYR, Malaysia, Mexico, Pakistan, Peru, Philippines, Poland, Russia Federation, Saudi Arabia, Singapore, Slovakia, Slovenia, South Africa, Spain, Tajikistan, Tunisia, Turkey, Turkmenistan, Ukraine, Uzbekistan, Venezuela, Viet Nam. These are 23 transition economies (former communist countries), 25 non former communist emerging economies and 2 old European Union member States (Spain and Ireland), included in the sample as reference countries for current emerging economies.

9 Table 2 explains this apparent contradiction.
} 
Table 1 Economic growth in ETEs

OLS model-Obs 50 dependent variable: economic growth 1995-2006

\begin{tabular}{lr}
\hline Variables & \multicolumn{1}{c}{ Coefficient } \\
\hline Poverty (1993) & $0.060977 *(0.012766)$ \\
Poverty variation (1993-2004) & $0.008892^{*}(0.002588)$ \\
Voice and accountability (1998-2005) & $-0.830378^{*}(0.394578)$ \\
Government effectiveness (1998-2005) & $1.499615 *(0.467849)$ \\
Life expectancy growth (1995-2004) & $-0.165477 *(0.051299)$ \\
Life expectancy (1995) & $0.236490 *(0.069520)$ \\
Constant & $-14.60425 *(5.180183)$
\end{tabular}

$R^{2} 0.547555$

Adjusted $R^{2} 0.469993$

Log likelihood -69.94339

Durbin-Watson stat 1.524590

Mean dependent var 4.752131

Prob $(F$ statistic) 0.000055

Standard Errors (in parenthesis) are heteroschedasticity-robust after White test. Multicollinearity not relevant

Source: own elaboration on Heston et al. (2006), UNDP (2006) data and Kaufmann et al. (2006)

* Significance level at $1 \%$

** Significance level at $5 \%$

\section{Poverty}

In order to answer to this question I used the sample of 50 ETEs described above. In the first regression below I found that economic growth in 1995-2006 was associated with more poverty, less democracy, as underlined by the coefficient voice and accountability, more authoritarianism, as underlined by the coefficient government effectiveness, and with negative variation of life expectancy during the period 1995-2004.

In the regression Table 1, it is surprising to see how well the observed variables fit with economic growth. In particular, an initial high level of poverty in 1993, an increasing level of poverty (1993-2004), a negative value of the indicator voice and accountability between 1998 and 2005 (a proxy for democracy and pluralism), a positive value of the indicator Government Effectiveness ${ }^{10}$ and a negative variation of life expectancy from 1995 to 2004, despite an initial higher level of the latter, are

${ }^{10}$ Both voice and accountability and Government Effectiveness are World Bank indicators of Governance. World Bank indicators, elaborated by Kaufmann et al. (2008) reflect the statistical compilation of responses on the quality of governance given by a large number of enterprise, citizen and expert survey respondents in developed, transition and developing countries, as reported by a number of survey institutes, think tanks, non-governmental organisations, and international organisations. Indexes are estimated between -2.5 and +2.5 . They concern five fundamental governance dimensions: voice and accountability, Political Stability, Government Effectiveness, Regulatory Quality, Rule of Law and Control of Corruption. Slovenia, Hungary, Estonia, the Czech Republic and Poland have the highest indicators. 
all functions of the economic growth that occurred during 1995-2006. The values of these variables do not identify a process of development of quality. Growth occurred at the expense of fundamental development variables such as life expectancy, poverty, and voice and accountability. The fact that an initial higher level of life expectancy, in 1995, is also functional to economic growth does not contradict the results; it just underlines that life expectancy, initially higher, declined during the process of economic growth (Table 2).

By contrast, a process of development of quality, High Quality Growth, is brought about when there is an improvement in human development variables, causing an increasing of the Human Development Index (HDI); this is an alternative means of measuring well being to GDP per capita (UNDP 1990). The UNDP Human Development Index is a composite index, ranking between 0 and 1 . It is the combination of two non-income dimensions of people's lives and one income dimension. The first one is life expectancy at birth which also reflects infant mortality; the second is educational attainment which is a combination of primary, secondary and tertiary educational levels and adult literacy rate. The third element is an adjusted GDP index which reflects income per capita measured in Purchasing Power Parity (PPP) at US\$ (UNDP 1990). In fact, the idea that the GDP is an absolute and reliable measure of development has been widely criticized by development economists (Morris 1979; Sen 1985; Noorbakhsh 1996). A great deal of empirical evidence shows that, both in developing and in developed economies, some countries have relatively high GDP per capita but very low indicators of development such as literacy, access to drinking water, rate of infant mortality, life expectancy, education, etc. This is partly due to the fact that wealth is unequally distributed. Conversely, there are cases of relatively low GDP per capita and high indicators of development in countries where income is more equally distributed (Ray 1998). ${ }^{11}$

The HDI is determined, in the following regression, by voice and accountability and low poverty. In the sample, countries having a lower poverty level (2004) and higher voice and accountability 1998-2004 also have a higher HDI 2004-which is indeed different from having a higher GDP per capita.

The results of the regression in Table 3, which is in a sense the reverse of the regression in Table 1, confirm my hypothesis. Among ETEs, countries with a higher level of development-represented here by the index HDI-would have lower

\footnotetext{
11 For instance, Guatemala has a GDP per capita that is higher than Sri Lanka but inequality is much higher in Guatemala. Development indicators are much better in Sri Lanka than in Guatemala. Life expectancy (years): 72 compared with 65; infant mortality rate (per 1000): 18 compared with 48; access to safe water (\% of pop.): 60 compared with 62 ; adult literacy rate $(\%): 89$ compared with 54 (UNDP, 1995). Examples like this are numerous and non-perfect correspondence between GDP and development indicators can be observed even in industrialized countries where there are more resources to distribute. For instance, Ireland has the highest GDP per capita after Luxemburg yet its non-income dimension indicators i.e., education and life expectancy are lower than Italy or Portugal (UNDP 2006). Saudi Arabia has a GDP per capita which is higher than many transition economies such as Poland Czech Republic, Hungary etc., but its non-income dimension indicators are lower. The US has an income per capita which is much higher than most of the countries in the world, yet life expectancy of black American citizens is lower than in China or in the Indian State of Kerala. As a result of all these contradictions and exceptions, the UNDP taxation of Human Development Indexes and GDP rank is not at all coincident (UNDP 1999).
} 


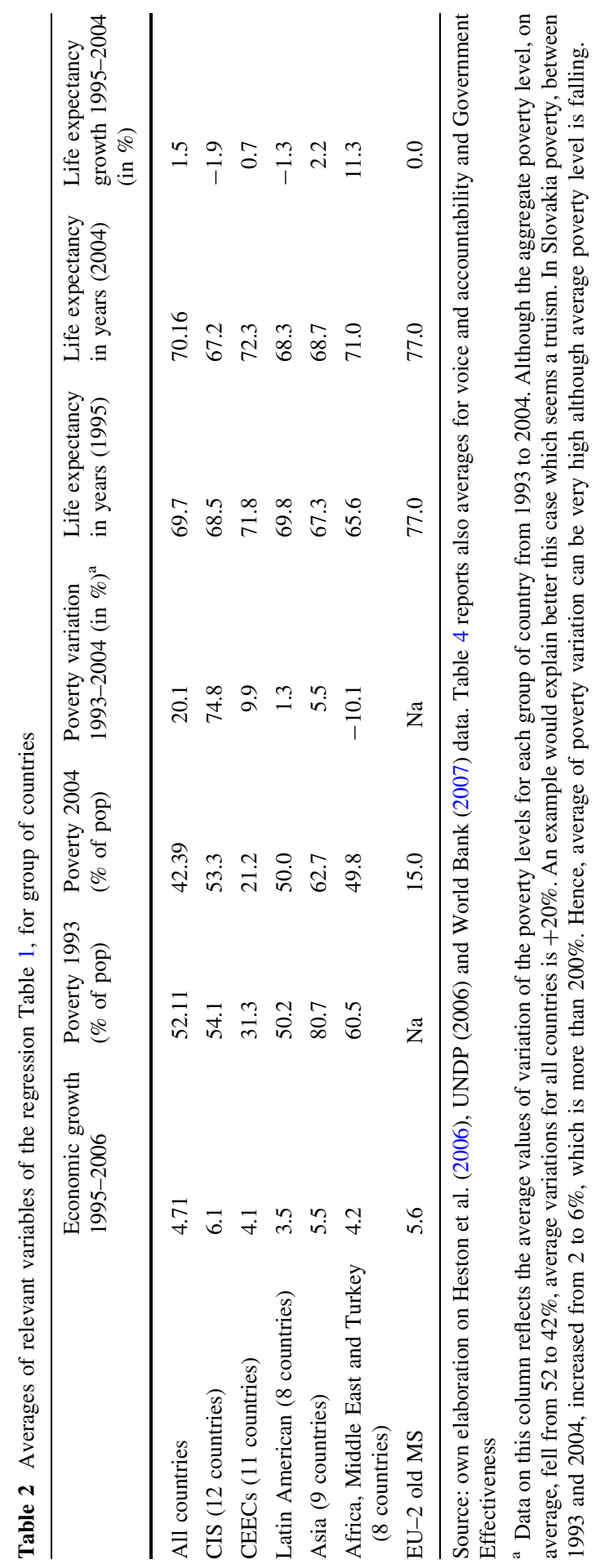


Table 3 HDI in ETEs

\begin{tabular}{|c|c|c|c|}
\hline \multicolumn{4}{|c|}{ OLS model-Obs 50 dependent variable: Human Development Index 2004} \\
\hline \multicolumn{2}{|l|}{ Variables } & \multicolumn{2}{|c|}{ Coefficients } \\
\hline \multicolumn{2}{|l|}{ Voice and accountability 1998-2005 } & \multicolumn{2}{|r|}{$0.026915 *(0.009763)$} \\
\hline \multicolumn{2}{|l|}{ Poverty (variation 1993-2004) } & \multicolumn{2}{|r|}{$-0.002351 *(0.000316)$} \\
\hline \multirow{2}{*}{\multicolumn{2}{|c|}{$\begin{array}{l}\text { Constant } \\
R^{2} 0.696647\end{array}$}} & \multicolumn{2}{|r|}{$0.886631 *(0.015218)$} \\
\hline & \multicolumn{3}{|c|}{$R^{2} 0.696647$} \\
\hline \multicolumn{4}{|l|}{ Adjusted $R^{2} 0.683165$} \\
\hline \multicolumn{4}{|l|}{ Log likelihood 75.52770} \\
\hline \multicolumn{4}{|l|}{ Durbin-Watson stat 2.111577} \\
\hline \multicolumn{4}{|l|}{ Mean dependent var 0.786104} \\
\hline \multicolumn{4}{|l|}{ Prob $(F$ statistic) 0.000000} \\
\hline \multirow{2}{*}{\multicolumn{4}{|c|}{$\begin{array}{l}\text { Standard errors (in parenthesis) are heteroschedasticity-robust after White } \\
\text { relevant } \\
\text { Source: own elaboration on UNDP (2006) and World Bank (2007) data } \\
\text { * Significance level at } 1 \%\end{array}$}} \\
\hline & & & \\
\hline & $\begin{array}{l}\text { HDI } 04 \\
\text { (between min } \\
0 \text { and } \max \text { ) }\end{array}$ & $\begin{array}{l}\text { Voice and accountability } \\
\text { average } 1998-2004 \\
(\min -2.5 \max +2.5)\end{array}$ & $\begin{array}{l}\text { Government effectiveness } \\
\text { average } 1998-2004 \\
(\min -2.5 \max +2.5)\end{array}$ \\
\hline All countries & 0.788 & -0.06 & 0.02 \\
\hline CIS (12 countries) & 0.746 & -0.9 & -0.7 \\
\hline CEECs (11 countries) & 0.848 & 0.7 & 0.5 \\
\hline Latin American (8 countries) & 0.792 & 0.2 & -0.2 \\
\hline Asia ( 9 countries) & 0.699 & -0.7 & -0.1 \\
\hline $\begin{array}{l}\text { Africa, Middle East and Turkey } \\
\text { (8 countries })\end{array}$ & 0.733 & -0.3 & 0.0 \\
\hline EU-2 old MS & 0.947 & 1.2 & 1.5 \\
\hline
\end{tabular}

Source: own elaboration on UNDP (2006) data and Kaufmann et al. (2006)

poverty and higher political democracy, represented by the index voice and accountability (Table 4).

Interestingly enough, poverty appears to be reduced by three variables: public expenditure in education, public expenditure in health, and political stability (see Table 5). Political stability is an important indicator, which in general is a consequence of cohesion and social peace; in this circumstance, it is most likely that appropriate poverty reduction policies have been implemented. Conversely, economic growth (1995-2006) did not contribute to poverty reduction as the coefficient for the variable economic growth (1995-2006) is not significant (see II regression). A predictable model which would represent poverty reduction and which is in fact confirmed by the result below is the following: 
Table 5 Poverty in ETEs (1)

\begin{tabular}{|c|c|c|c|}
\hline \multicolumn{4}{|c|}{ OLS model-Obs 50 dependent variable: poverty 2004} \\
\hline \multicolumn{2}{|l|}{ I Regression } & \multicolumn{2}{|l|}{ II Regression } \\
\hline Variables & Coefficient & Variables & Coefficient \\
\hline $\begin{array}{l}\text { Public education } \\
\text { expenditure average } \\
\text { 2000-2004 }\end{array}$ & $-5.128180 *(1.833510)$ & $\begin{array}{l}\text { Education expenditure } \\
2000-2005\end{array}$ & $-5.133575 *(1.857425)$ \\
\hline $\begin{array}{l}\text { Public heath } \\
\text { expenditure average } \\
2000-2004\end{array}$ & $-8.742550 *(1.853532)$ & $\begin{array}{l}\text { Heath expenditure } \\
\text { 2000-2005 }\end{array}$ & $-8.832262 *(1.897523)$ \\
\hline \multirow[t]{2}{*}{$\begin{array}{l}\text { Political stability } \\
\text { 2000-2004 }\end{array}$} & $-9.256239 * *(3.685674)$ & $\begin{array}{l}\text { Political stability } \\
\text { 2000-2005 }\end{array}$ & $-9.296939 * *(3.735670)$ \\
\hline & & $\begin{array}{l}\text { Economic growth } \\
1995-2006\end{array}$ & $-0.551997(1.685981)$ \\
\hline Constant & $95.83431 *(9.177251)$ & Constant & 98.75598 (12.88641) \\
\hline \multicolumn{2}{|l|}{$R^{2} 0.6512$} & \multicolumn{2}{|l|}{$R^{2} 0.6514$} \\
\hline \multicolumn{2}{|l|}{ Adjusted $R^{2} 0.6274$} & \multicolumn{2}{|l|}{ Adjusted $R^{2} 0.6189$} \\
\hline \multicolumn{2}{|c|}{ Log likelihood -163.7369} & \multicolumn{2}{|c|}{ Log likelihood -163.6755} \\
\hline \multicolumn{2}{|c|}{ Durbin-Watson stat 1.985574} & \multicolumn{2}{|c|}{ Durbin-Watson stat 1.966940} \\
\hline \multicolumn{2}{|c|}{ Mean dependent var 42.51769} & \multicolumn{2}{|c|}{ Mean dependent var 42.51769} \\
\hline \multicolumn{2}{|c|}{ Prob ( $F$ statistic) 0.000000} & \multicolumn{2}{|c|}{ Prob $(F$ statistic) 0.000001} \\
\hline
\end{tabular}

Standard Errors (in parenthesis) are heteroschedasticity-robust after White test. Multicollinearity not relevant

Source: own elaboration on Heston et al. (2006), UNDP (2006) and World Bank (2007) data, Kaufmann et al. (2006)

* Significance level at $1 \%$

** Significance level at $5 \%$

$$
\text { Poverty }=\alpha-\beta_{1} \cdot \text { Edu }-\beta_{2} \cdot \text { Health }-\beta_{3} \text { Pol.Stab }+\varepsilon
$$

In other words poverty increases when public expenditure in education and in health decreases and when political troubles and political instability increases.

A theoretical explanation of this evidence can be traced back to Amartya Sen's thought. Since public expenditure in education and health would improve education level and life expectancy, crucial indicators of development, poverty will be reduced because individual capabilities of doing and being will increase (Sen 1999).

Another way of seeing the relation represented in Table 6 is to regress Poverty (2004) with infant mortality reduction (1975-1995) (a good proxy also for health public expenditure), and adult literacy variation (1990/1995) (a good proxy also for education expenditure). Similarly, economic growth (1995-2006) does not appear to be significant in this regression. Basically, the evidence which emerges from this exercise is that poverty is lowered by infant mortality reduction (1970-1995) that occurred previously to the current economic growth. The variable Adult literacy in 1990/1995 is also significant, in the sense that an initial higher level of education would cause a lower level of poverty (Table 7). 
Table 6 Averages of relevant variables of the regression Table 5, for group of countries

\begin{tabular}{llll}
\hline & $\begin{array}{l}\text { Political stability average } \\
1998-2004(\mathrm{~min}-2.5 \\
\max +2.5)\end{array}$ & $\begin{array}{l}\text { Heath expenditure } \\
\text { average 2000-2004 } \\
(\% \text { of GDP })\end{array}$ & $\begin{array}{l}\text { Education expenditure } \\
\text { average 2000-2004 } \\
(\% \text { of GDP) }\end{array}$ \\
\hline All countries & -0.04 & 3.3 & 4.5 \\
CIS (12 countries) & -0.7 & 2.3 & 5.8 \\
CEECs (11 countries) & 0.4 & 5.1 & 5.3 \\
Latin American (8 countries) & 0.1 & 3.0 & 3.2 \\
Asia (9 countries) & -0.1 & 1.5 & 3.1 \\
Africa, Middle East and Turkey & -0.5 & 3.6 & 5.2 \\
$\quad(8$ countries) & & & 4.7 \\
EU - 2 old MS & 0.8 & 5.7 & \\
\hline
\end{tabular}

Source: own elaboration on UNDP (2006) data and Kaufmann et al. (2006)

Table 7 Poverty in ETEs (2)

OLS model-Obs 50 dependent variable: poverty 2004

\begin{tabular}{|c|c|c|c|}
\hline \multicolumn{2}{|l|}{ Regression I } & \multicolumn{2}{|l|}{ Regression II } \\
\hline Variables & Coefficient & Variables & Coefficient \\
\hline $\begin{array}{l}\text { Infant mortality } \\
\text { reduction } 1970-1995\end{array}$ & $-0.6186608 *(0.125173)$ & $\begin{array}{l}\text { Infant mortality } \\
\text { reduction 1970-1995 }\end{array}$ & $-0.5632049 *(0.1330992)$ \\
\hline \multirow[t]{2}{*}{$\begin{array}{l}\text { Adult literacy 1990/ } \\
1995\end{array}$} & $-1.054593 *(0.202224)$ & $\begin{array}{l}\text { Adult literacy 1990/ } \\
1995\end{array}$ & $-1.066044 *(0.2015496)$ \\
\hline & & $\begin{array}{l}\text { Economic growth } \\
\text { 1995-2006 }\end{array}$ & $1.1281490(1.711285)$ \\
\hline Constant & $170.3155^{*}(20.2291)$ & Constant & $159.3541 *(22.15867)$ \\
\hline \multicolumn{2}{|l|}{$R^{2} 0.5078$} & \multicolumn{2}{|l|}{$R^{2} 0.5231$} \\
\hline \multicolumn{2}{|l|}{ Adjusted $R^{2} 0.4860$} & \multicolumn{2}{|l|}{ Adjusted $R^{2} 0.4906$} \\
\hline \multicolumn{2}{|c|}{ Log likelihood -211.2259} & \multicolumn{2}{|c|}{ Log likelihood -210.92220} \\
\hline \multicolumn{2}{|c|}{ Durbin-Watson stat 2.149447} & \multicolumn{2}{|c|}{ Durbin-Watson stat 2.181335} \\
\hline \multicolumn{2}{|c|}{ Mean dependent var 42.38229} & \multicolumn{2}{|c|}{ Mean dependent var 42.38229} \\
\hline \multicolumn{2}{|c|}{ Prob ( $F$ statistic) 0.000001} & \multicolumn{2}{|c|}{ Prob ( $F$ statistic) 0.000005} \\
\hline
\end{tabular}

Standard errors (in parenthesis) are heteroschedasticity-robust after White test. Multicollinearity not relevant

Source: own elaboration on Heston et al. (2006), UNDP (2006) data and Kaufmann et al. (2006)

* Significance level at $1 \%$

Hence, it can be concluded from these regression results in Tables 5 and 6 that economic growth occurred during the last decade did not contribute to a reduction in poverty or to an increase in human development variables. On the contrary poverty appears to be much lower in countries enjoying higher levels of political stability, and which improved human development variables such as infant mortality and adult literacy during the period before the current economic growth, and thanks to public investments in the health system and in education (Table 8). 
Table 8 Averages of relevant variables of the regression Table 7, for group of countries

\begin{tabular}{lll}
\hline & $\begin{array}{l}\text { Adult literacy 1990/1995 } \\
\text { (\% of pop) }\end{array}$ & $\begin{array}{l}\text { Reduction of infant } \\
\text { mortality 1970-1995 (in \%) }\end{array}$ \\
\hline All countries & 90 & 55.4 \\
CIS (12 countries) & 99 & 30.7 \\
CEECs (11 countries) & 97 & 56.7 \\
Latin American (8 countries) & 90 & 62.3 \\
Asia (9 countries) & 75 & 52.5 \\
Africa, Middle East and Turkey (8 countries) & 74 & 70.2 \\
EU-2 old MS & 98 & 73.9 \\
\hline
\end{tabular}

Source: own elaboration on UNDP (2006) data

Inequality

During the last 10-15 years ETEs experienced an increasing trend in the Gini coefficient. In the sample of ETEs, the average of Gini, in 1993, was 37\%, while in 2004 it was above 39\%. The average of Gini variation for the same period was $+7 \%$. The lowest values of Gini are in Slovakia and the Czech Republic (25.8\%), Hungary (27\%) and Slovenia (28\%), among former communist countries, and in South Korea $(31 \%)$ for non communist countries. The highest values are in Botswana (61\%), Bolivia (60\%), South Africa, Chile and Brazil (57\%) and, for former communist countries, in Russia (42\%) (Table 9).

Hence, although economic growth occurred for a quite long period (1995-2006), inequality did not decrease as predicted by a hypothetical inverted "U"-shaped Kuznets curve. The following figure invalidates such a hypothesis, scattering ETEs in two periods, in the 1990s and in the 2000s, with GDP per capita on the horizontal axis and Gini on the vertical axis (Fig. 2).

Why did income inequality increase? I assume because education and other human development variables (such as life expectancy) worsened. Consecutively, income distribution worsened. A theoretical model which would represent such a prediction would be the following:

$$
\text { Gini }=\alpha-\beta_{1} \cdot \text { literacy }-\beta_{2} \cdot \text { lifeExpe }-\beta_{3} \cdot \text { PubExpe }+\varepsilon
$$

In order to test such a hypothesis I used an OLS regression model in the usual sample of 50 ETEs. The results are very interesting, although are a bit more complex than the model above, as shown in Table 10. The Gini coefficient in 2004 is negatively correlated with Adult literacy in 2004, Adult literacy growth (19952004), Public expenditure (2000-2005) and life expectancy growth eventually occurring before the current economic growth (1970-1995). Economic growth (1995-2006), which would increase income inequality in this model by a coefficient of $\beta=0.2410$, is not statistically significant (cf. Regression II).

Education and public expenditure are crucial variables in this model for a reduction of income inequality. Public expenditure finances, among other, a national health system with positive advantages for life expectancy, which should grow too in order to reduce income inequality. Life expectancy grew consistently before the 


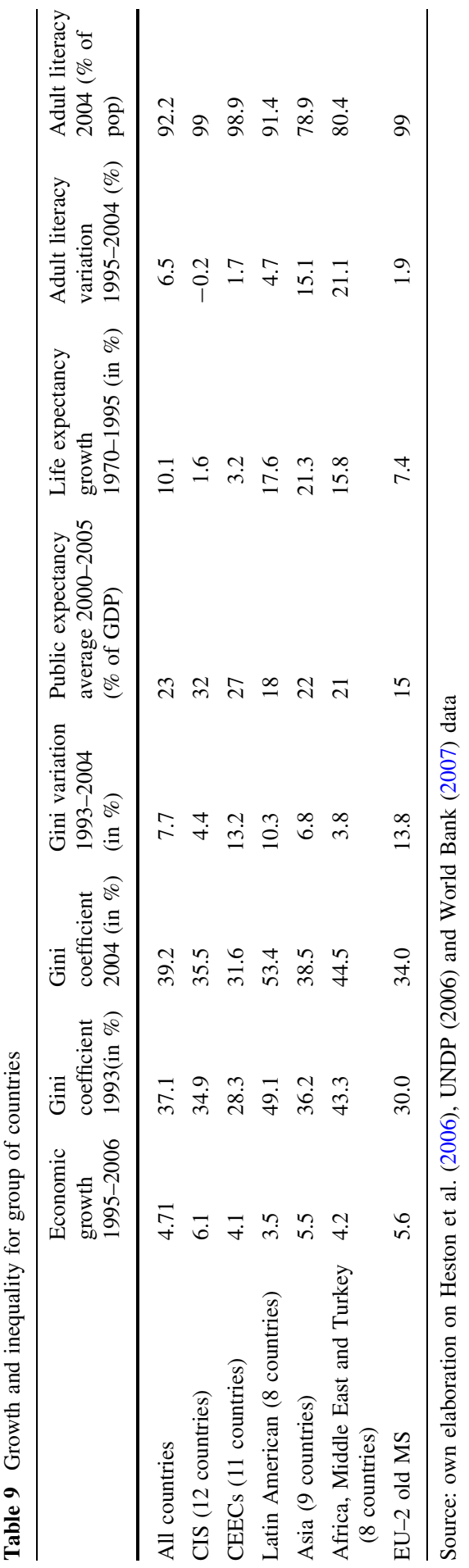



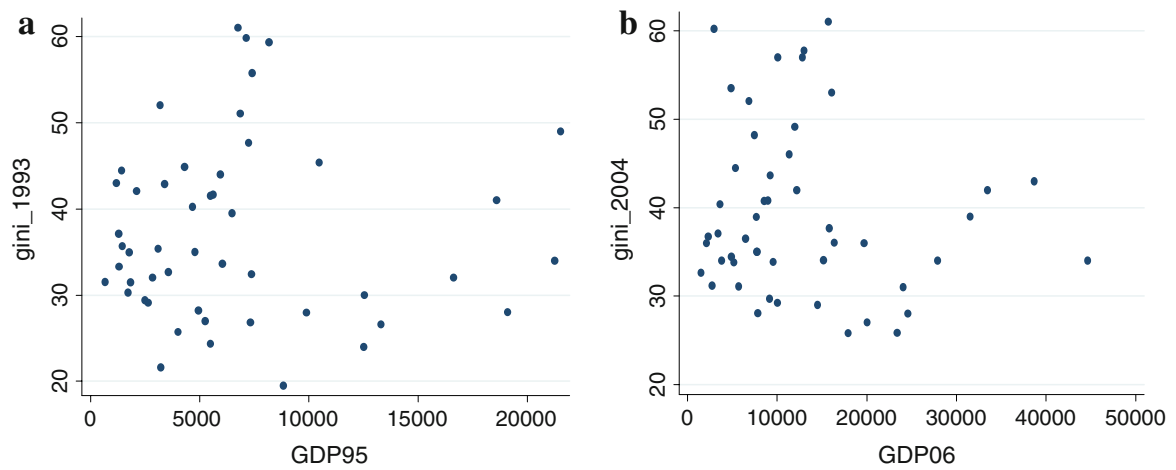

Fig. 2 a Gini 1993 versus GDP per capita 1995. b Gini 2004 versus GDP per capita 2006. Source: own elaboration on World Bank (2007) data

Table 10 Income inequality

OLS model-Obs 50 dependent variable: GINI 2004

\begin{tabular}{|c|c|c|c|}
\hline \multicolumn{2}{|l|}{ Regression I } & \multicolumn{2}{|l|}{ Regression II } \\
\hline Variables & Coefficient & Variables & Coefficient \\
\hline Adult literacy 2004 & $-1.05157 *(0.151033)$ & Adult literacy 2004 & $-1.065728^{*}(0.155722)$ \\
\hline $\begin{array}{l}\text { Adult literacy growth } \\
\quad(1995-2004)\end{array}$ & $-0.5566862 *(0.1139592)$ & $\begin{array}{l}\text { Adult literacy growth } \\
\text { (1990-2004) }\end{array}$ & $-0.5663246^{*}(0.1170401)$ \\
\hline $\begin{array}{l}\text { Life expectancy } \\
\text { growth (1970-1995) }\end{array}$ & $\begin{array}{l}-0.3470506 \\
\quad(0.1298205)^{* *}\end{array}$ & $\begin{array}{l}\text { Life expectancy } \\
\text { growth }(1970-1995)\end{array}$ & $\begin{array}{r}-0.3456583^{* *} \\
(0.1310583)\end{array}$ \\
\hline $\begin{array}{l}\text { Public expenditure } \\
\quad(2000-2005)\end{array}$ & $\begin{array}{l}-0.3385873 \\
\quad(0.1291205)^{* *}\end{array}$ & $\begin{array}{l}\text { Public expenditure } \\
\quad(2000-2005) \\
\text { Growth (1995-2006) }\end{array}$ & $\begin{array}{l}-0.3460278 * * \\
(0.1313586) \\
0.241014(0.5423469)\end{array}$ \\
\hline Constant & $76.94141 *(5.969043)$ & Constant & $76.32705^{*}(6.180829)$ \\
\hline \multicolumn{2}{|l|}{$R^{2} 0.5599$} & \multicolumn{2}{|l|}{$R^{2} 0.5619$} \\
\hline \multicolumn{2}{|l|}{ Adjusted $R^{2} 0.5199$} & \multicolumn{2}{|l|}{ Adjusted $R^{2} 0.5110$} \\
\hline \multicolumn{2}{|c|}{ Log likelihood -174.6677} & \multicolumn{2}{|c|}{ Log likelihood -174.5815} \\
\hline \multicolumn{2}{|c|}{ Durbin-Watson stat 1.940153} & \multicolumn{2}{|c|}{ Durbin-Watson stat 1.952846} \\
\hline \multicolumn{2}{|c|}{ Mean dependent var 39.24} & \multicolumn{2}{|c|}{ Mean dependent var 39.24} \\
\hline \multicolumn{2}{|l|}{ Prob ( $F$ statistic) 0.0000} & \multicolumn{2}{|l|}{ Prob ( $F$ statistic) 0.0000} \\
\hline
\end{tabular}

$\overline{\text { Standard errors (in parenthesis) are heteroschedasticity-robust after White test. Multicollinearity not }}$ relevant

Source: own elaboration on Heston et al. (2006), UNDP (2006) and World Bank (2007) data

* Significance level at $1 \%$

** Significance level at $2 \%$

current economic growth in most of the ETEs as shown in Table 9. However, during 1995-2004, life expectancy worsened in many countries (cf. Table 2). This is the reason why the variables life expectancy variation between 1995 and 2004 and life expectancy in 2004 would not be significant in reducing inequality, and are 
therefore excluded from the regression in Table 10. In fact, following a capability approach, basic dimensions such as health and education should be guaranteed by public policies in order for people to live a long and healthy life, become knowledgeable and acquire a decent standard of living. If these basic capabilities are not achieved, many choices are simply not available and many opportunities remain inaccessible (UNDP 1999). Lack of opportunities will lead to income inequality and poverty. Very simply, if education is subject only to market rules, then higher education will be available only to children whose parents can pay market prices. Poorer parents, who in most of cases are unskilled workers, could not afford such a cost; consequently unskilled parents will tend to have unskilled children. In this way, inequality will be "crystallized" within the initial conditions and will not be reduced during economic growth. Moreover, if growth requires more and more skilled workers, inequality will increase accordingly.

It seems that economic growth in ETEs requires higher education and ignores basic education. This is confirmed by the increase, in all the emerging economies, of exports in the ICT sector (Unctad 2006), which of course has a high employment ratio of skilled workers. This is likely to be one of the elements of the growing inequality in ETEs. Unskilled workers, i.e., people with basic education, remain outside the socio-economic model of growth in ETEs, which includes skilled people with high education. Such a model produces education inequality and consecutively income inequality, with an increasing level of people at risk of poverty.

\section{Conclusion}

Using ETEs during the period 1995-2006, this paper analyses the process of development perceived as a wider process of economic growth and of institutional change bringing about poverty reduction and income distribution alongside an improvement in human development variables. During this period, ETEs experienced an acceleration growth in the sense of Rodrik et al. (2005), with average growth equal to $4.7 \%$, and above the world average growth. However, such a growth did not bring about a process of development as above defined. The results suggest that the economic growth occurring during the last decade contributed neither to a decrease in poverty between 1993 and 2004, measured through a cut-off line of $\$ 4$ a day, nor to an increase in human development variables, particularly in life expectancy. On the contrary, these variables worsened, as did voice and accountability, the proxy for political democracy and pluralism.

Income inequality, measured as a reduction of Gini coefficient between the years 1993 and 2004, worsened too. One can say that growth in ETEs occurred despite the worsening of income inequality. Nevertheless, this does not identify a "U-shaped" Kuznets curve because a subsequent inequality reduction, after a long period of growth (11 years) was not observed. On the contrary, inequality increased constantly. The results suggest also that countries with a lower level of adult literacy and public expenditure, suffer higher income inequality. Hence, inequality is not inevitable during economic growth but higher education and State intervention in strategic dimensions of human development may reduce inequalities; 
a more educated population and an active role of the state in creating equal opportunities increase individual capabilities with consequent positive effects on individuals' income.

In the same way poverty appears to be much lower when countries improved, during the period before the current economic growth, and thanks to public investments, human development variables such as infant mortality and adult literacy. Hence, the holistic role of the State, in the sense of Myrdal (1974) is crucial in reducing poverty. In fact, as the regression results suggest, the public expenditure in education and health increases skills and life expectancy, and provides great opportunities, essential for escaping the poverty trap, and for people to build creative and long lives. On the contrary, lack of opportunities will lead to both income inequality and poverty.

Open Access This article is distributed under the terms of the Creative Commons Attribution Noncommercial License which permits any noncommercial use, distribution, and reproduction in any medium, provided the original author(s) and source are credited.

\section{References}

Ahluwalia MS (1976) Inequality, poverty and development. J Dev Econ 3(4):307-342

Agtmael A (2007) The emerging markets century: how a new breed of world-class companies is overtaking the world. Free Press, New York

Alesina A, Perotti R (1996) Income distribution, political instability and investment. Eur Econ Rev 40:1203-1228

Alexander KC, Kumaran KP (1992) Culture and development cultural patterns in areas of uneven development. Sage Publications, New Delhi, Newbury Park and London

Atkinson A (1999) Is rising inequality inevitable? A critique of the transatlantique consensus. WIDER Annual Lectures No. 3, Helsinki

Atkinson A, Miklewright J (1992) Economic transformation in Eastern Europe and the distribution of income. Cambridge University Press, Cambridge

Birdsall N, Sabot R (1994) Inequality as a constraint on growth in Latin America, development policy, newsletter on policy research, Inter-American Development Bank

Brinkman R (1995) Economic growth versus economic development: toward a conceptual clarification. J Econ Issues 29:1171-1188

Chenery HB, Syrquin M (1975) Patterns of development, 1950-1960. University Press, Oxford

Cypher J, Dietz J (2004) The process of economic development, 2nd edn. Routledge, London and New York

Dollar D, Kraay A (2001) Growth is good for the poor? Policy Research Working Paper Series 2587, The World Bank

Easterly W (2001) The middle class consensus and economic development. J Econ Growth 6:317-335

Field G (1989) Changes in poverty and inequality in developing countries. World Bank Res Obs 4:167185

Gradstein M, Milanovic B (2004) Does Liberté = Egalité? A survey of the empirical links between democracy and inequality with some evidence on the transition economies. J Econ Surv 18(4):515537

Heston A, Summers R, Aten B (2006) Penn World Table Version 6.1, Center for International Comparisons of Production, Income and Prices University of Pennsylvania

Hodgson G (2006) What are institutions? J Econ Issues 44:1-25

IMF (1995) Gender issues in economic adjustment, IMF Survey, 25 Sept 1995, pp 286-288

IMF (2001) World Economic Outlook, A Survey by the Staff of the International Monetary Fund, World Economic and Financial Surveys

IMF (2007) World Economic Outlook, online database 
Kaufmann D, Kraay A, Mastruzzi M (2006) Governance matters VII: aggregate and individual governance indicators, 1996-2007, World Bank Policy Research

Kornai J (2006) The great transformation of Central Eastern Europe. Success and disappointment. Econ Transit 14:207-244

Kuznets S (1955) Economic growth and income inequality. Am Econ Rev 45:1-28

Kuznets S (1965) Economic growth and structure: selected essay. Norton, New York

Mabogunje AL (1989) The development process. A spatial perspective, 2nd edn. Unwin Hyman, London

Marcus R, Wilkinson J (2002) Whose poverty matters? Vulnerability, social protection and PRSPs, Working Paper No.1, Childhood Poverty Research and Policy Centre

Mauro P (2000) Stock returns and output growth in emerging and advanced economies, IMF Working Paper, No. 89, Washington DC

Milanovic B (1994) Determinants of cross-country income inequality: an augmented Kuznets hypothesis, Policy Research Working Paper Series 1246

Milanovic B (1995) Poverty, inequality, and social policy in transition economies, Policy Research Working Paper Series 1530, The World Bank

Milanovic B (1998) Explaining the increase in inequality during the transition, Policy Research Working Paper Series 1935, The World Bank

Morris DM (1979) Measuring the condition of the world's poor: the physical quality of life index. Pergamon Press, New York

Myrdal G (1974) What is development? J Econ Issues 8:729-736

Noorbakhsh F (1996) Some reflections on UNDP's Human Development Index, Cds occasional paper, n. 17, University of Glasgow

Nugent JB, Lin JY (1995) Institutions and economic development. In: Chenery H, Srinivasan TN, Behrman J (eds) Handbook of development economics, North-Holland

Perkins D, Dwight H, Radelet S, Lindauer D (2007) Economics of development, 6th edn. ISI

Pronk J (1993) The World Bank and Poverty Reduction, Netherlands, Ministry of Foreign Affairs, The Hague

Rawls J (1971) A theory of justice. Harvard University Press, Cambridge

Ray D (1998) Development economics. Princeton University Press, Princeton

Rodrik D, Hausmann R, Pritchettm L (2005) Growth accelerations. J Econ Growth 10:303-329

Sen A (1973) On economic inequality. Clarendon Press, Oxford, England

Sen A (1985) A sociological approach to the measurement of poverty: a reply to prof. Peter Townsend, Oxford Econ Papers n. 37

Sen A (1999) Development as freedom. Oxford University Press, New York

Sokoloff K, Engerman S (2000) History lessons institutions, factor endowments, and paths of development in the new world. J Econ Perspect 14:217-232

Street JH (1987) The institutionalist theory of economic development. J Econ Issues 21:1861-1888

Toye J (1995) The new Institutional Economics and its implications for development theory. In: Harris J, Unter J, Lewis C (eds) The new institutional economics and third world development, Routledge

Tridico P (2006) Institutional change and Governance Indexes in transition economies: the case of Poland. Eur J Comp Econ 3:197-238

Unctad (2006) Statistical yearbook, online database

UNDP, Human Development Report, 1990, 1995, 1999, 2000, 2004, 2006. Oxford University Press

Veblen T (1919) The place of science in modern civilization. The Viking Press, New York

Voitchovsky S (2005) Does the profile of income inequality matter for economic growth? Distinguishing between the effects of inequality in different parts of the income distribution. J Econ Growth 10:273-296

World Bank (1990) World Development Report. Oxford University Press

World Bank (1998) East Asia: the road to recovery. Washington DC

World Bank (2000) World Development Report. Oxford University Press

World Bank (2007) Millennium development goals, online database 